\title{
PLATÓN: DEMOCRACIA Y FILOSOFÍA
}

José Molina Ayala*

RESUMEN: Sintetizada en extremo, la biografía de Platón muestra fuertes vínculos entre sus ideales políticos, el desarrollo de su pensamiento -ético, metafísico, gnoseológico- y la realidad política. Paradójicamente, en el Estado que propugna Platón, quizá no habría habido lugar para alguien como su maestro: Sócrates y el mismo Platón fueron, sin duda, fruto de la democracia.

Palabras ClaVe: Platón, democracia, filosofía, ideas, diálogos.
ABSTRACT: Plato's life and the important links between his political ideals, the development of his thought about ethics, metaphysics, and gnoseology, and political reality will be presented. Paradoxically, the State which Plato proposes would not have had a role for his teacher, Socrates. Plato and Socrates are without a doubt products of democracy.

KEYWORDS: Plato, democracy, philosophy, ideas, dialogues.

* Centro de Estudios Clásicos, Instituto de Investigaciones Filológicas, UNAM.
RECEPCIÓN: 5 de marzo de 2008.

ACEPTACIÓN: 23 de mayo de 2008. 


\section{PLATÓN: DEMOCRACIA Y FILOSOFÍA}

Aristocles, mejor conocido como Platón a causa de sus amplias espaldas, fue hijo de Aristón y de Perictione, noble aristócrata que remontaba su linaje hasta el sabio Solón, fundador de la democracia ateniense. Cuando Platón nació, hacia el 428 a.C. (todas las fechas son anteriores a nuestra era), su ciudad era el centro político y cultural más importante del mundo, emblema del poderío democrático; la Acrópolis, junto con el Partenón, lucía majestuosa, y el Ágora, la plaza pública, era frecuentada por los mejores poetas, artistas, intelectuales, oradores. Allí, Platón pudo tener la mejor educación y pronto destacó como escritor de poesía dramática; fue tal vez alumno de Crátilo, discípulo del filósofo Heráclito. Ahora bien, para su formación, resultaron determinantes dos factores mutuamente implicados: el primero fue el desarrollo de la Guerra del Peloponeso - conflicto entre Atenas y Esparta, ciudades hegemónicas de bandos opuestos entre las ciudades helenas, iniciado en el 431-; y el segundo fue haber conocido, el año 409 a sus veinte años, al filósofo Sócrates, de sesenta y tres. Platón verá trastornado su futuro como político y como dramaturgo, pues, tras quemar sus obras, se entregará a la filosofía, cuya misión en el ideario socrático era aguijonear sin tregua, como un tábano, a todos los ciudadanos para que fueran virtuosos.

La democracia ofrece la igualdad política a los ciudadanos; todos, sin importar su linaje o su riqueza, por derecho o por obligación, deciden las acciones que habrán de emprenderse; a veces se acierta, y otras, 
no pocas, se cometen errores. Atenas decidió, incluso habiendo firmado un acuerdo de paz en 421 (la llamada Paz de Nicias), continuar su política expansionista y reanudar el conflicto contra Esparta. En el 404 termina la guerra con la derrota ateniense; los muros de la ciudad deben ser derribados, y con ellos la democracia, que sucumbe ante la llamada tiranía de Los Treinta. Entre ellos están Carmides y Critias, parientes de Platón. El terror se impone; hay ejecuciones sumarias y a varios demócratas se les impone el exilio. La democracia se restaura en 403 , y en el 399, Platón a sus treinta años ve a su maestro, a diez años de haberlo conocido, condenado a muerte por la democracia. Fue profunda la herida en el ánimo platónico; de hecho, su obra puede entenderse como una pertinaz oposición a la democracia, al punto que incluso se ha llegado a considerar fuente de totalitarismo a su pensamiento. Así pues, Platón no encuentra ningún sentido en participar directa y activamente en la política bajo ese régimen; viaja hacia Megara, donde pasa un tiempo en compañía del socrático Euclides, y en 395, prestará servicio militar en la guerra de Corinto.

En su mente se agita el relativismo de Protágoras que ensalzaba "al hombre, medida de todas las cosas", y el de Gorgias, que ironiza a los filósofos: "el ser no existe; si existiera, no lo podemos conocer; si lo conociéramos, no lo podríamos comunicar". La democracia fácilmente degenera, por la demagogia, en anarquía, y ésta en tiranía. ¿Qué hacer? ¿Cómo oponerse? Platón se da, entonces, a la tarea de colocar fundamentos sólidos a la realidad, al conocimiento, al gobierno. Usando sus dotes de poeta dramático, escribe 'diálogos', un género nacido en el círculo socrático en que se 'recrean' los encuentros del maestro con distintos personajes de la ciudad. En sus Diálogos, Platón hace vacilar en sus convicciones, aparentemente firmes, a los hombres supuestamente más capacitados para responder a las interrogantes: los poetas, los geómetras, los rétores, los generales, los sofistas; ironiza, impugnándola él mismo, la actitud sofística de que todo es impugnable: en el fondo se trata de un método de investigación en que distintos temas son debatidos en cada diálogo. Se busca llegar, mediante la dialéctica (arte de enfrentar posiciones opuestas, para alcanzar una verdad superior; distinguible de la erística, arte de impugnar lo que sea), a fundamentos cada vez más seguros, sin fijar conclusiones definitivas; inclusive, en los Diálogos suele no llegarse a ninguna conclusión, y por eso se llaman 'aporéticos', esto es, 'sin salida'. En esta etapa escribe: Apología; Critón (sobre el deber); Protágoras (sobre la virtud y la edu- 
cación); Ión (sobre la poesía); Hipias mayor (sobre lo bello); Hipias menor (sobre lo falso); Eutidemo (contra la erística); Laques (sobre la valentía); Carmides (sobre la temperancia); Eutifrón (sobre lo santo); Lysis (sobre la amistad); y El libro I de La República (sobre la justicia).

Hacia el 388 realiza el primero de tres viajes a Sicilia. Entra en contacto con los pitagóricos, en particular con Arquitas en Tarento y con Timeo en Locros. A diferencia de las frugales costumbres de los pitagóricos, el lujo de los griegos establecidos en la Magna Grecia aparece a sus ojos como causa de inestabilidad política. En Siracusa, en la corte del tirano Dionisio I, se hace amigo de Dión, cuñado del tirano. Se habla de una estancia de Platón en Cirene, con el matemático Teodoro, e incluso se cree que habría viajado a Egipto. Tal vez durante su estancia en la Magna Grecia, por su contacto con comunidades órficas y dionisíacas entregadas a cultos mistéricos, Platón pudo incubar los posteriores mitos sobre el mundo del más allá que incluirá en sus obras. El final del viaje no fue feliz: habiéndose embarcado en una nave espartana, Platón fue hecho esclavo. Sólo pudo recobrar su libertad gracias a que, en la isla de Egina, Aniqueris de Cirene lo reconoció y pagó su rescate.

De vuelta en Atenas funda su escuela, junto al río Céfiso, donde estaba la tumba del héroe Academo, rodeada por un bosque sagrado. Es difícil saber a ciencia cierta la organización de la Academia; ciertamente es un error ver en ella el antecedente de las universidades, pues se trata más bien de una comunidad de intelectuales aristócratas que comparten, por así decirlo, su bienes espirituales; su objetivo era capacitar a los jóvenes para configurar su vida de acuerdo con los fundamentos de la filosofía platónica. Además, la Academia enfrentó a otra escuela más famosa entonces, la fundada por Isócrates, que propugnaba por unos ideales más inmediatos de la educación y entregada a la retórica. En la Academia, en cambio, las matemáticas fueron muy importantes: "nadie entre que no sepa geometría" rezaba un letrero a la entrada, y allí mismo florecerá todo tipo de conocimiento teórico y elevado, aunque no tuviera un carácter utilitario. Se pregunta, ¿qué es la ciencia?, ¿qué es el lenguaje?, ¿qué es lo que se conoce y qué es lo que conoce?, ¿qué es la justicia?

Así pues, en la Academia se desarrolla el pensamiento platónico. Platón escribe entonces Gorgias (sobre la retórica); Crátilo (sobre la corrección de los nombres); Menón (sobre la virtud); Fedón (sobre el alma); Banquete (sobre el bien); República (sobre lo justo); Fedro (sobre el amor); Parménides (sobre las 
ideas); y Teeteto (sobre la ciencia). La fama de Platón y de la Academia se extiende por toda la Hélade y, hacia el 367, ingresa su mejor alumno: Aristóteles, que durará allí veinte años y fundará después su propia escuela: el Liceo.

Es imposible describir en pocas líneas la doctrina platónica, pero puede apuntarse lo siguiente como rasgos sobresalientes: a la realidad no la pueden conocer los sentidos; sólo el verdadero ser del hombre, que es su alma, conoce la realidad; el alma debe ser inmortal, precisamente para ser capaz de conocer la verdad, que, para ser verdad, debe también ser eterna. Pero la realidad no puede ser sólo o básicamente el mero mundo material, porque la corruptibilidad del mundo sensible, el hecho de que esté sometido al cambio, tampoco satisface el conocimiento de lo verdadero que debe ser inmutable. Platón postula entonces la existencia de las ideas, la realidad verdadera que conoce el alma, mundo alternativo, modelo de este mundo, cuyo sol es la idea del Bien. Así pues, sólo hay verdadera ciencia cuando el alma, sola consigo misma y separada del cuerpo gracias a la reflexión y al intelecto, conoce las ideas, mientras que del mundo material sólo puede haber creencia y opinión.

Ahora bien, para Platón el ser humano es un alma encerrada en un cuerpo, y debe, mediante las virtudes que se consiguen gracias a la dialéctica o al amor, purificar su alma durante su vida mortal para poder volver al final de sus días terrenos a ese otro mundo que compartía con los dioses, donde están las ideas. El hombre por medio de la filosofía puede aprender, desde esta vida, a separar al alma del cuerpo. La filosofía se define, casi sin metáfora, como 'aprender a morir'. De no hacerlo, al final de sus días, en vez de recobrar su anterior estado de alma pura, volverá a encarnarse en otro cuerpo.

A su vez, el alma misma se divide en tres partes: la parte principal le corresponde a la facultad racional, que debe subordinar a las otras dos, que son el apetito concupiscible (los deseos y apetencias del cuerpo) y el irascible (deseos de honores, gloria, fama). La virtud de la temperancia pone en orden al apetito concupiscible; la virtud de la valentía somete al apetito irascible; la prudencia es la virtud de la parte racional. Si se dan las tres virtudes, se genera la justicia. Platón concibe entonces un juego de correspondencias entre el hombre individual y el Estado. Éste también debe componerse de tres clases sociales que corresponden a cada parte del alma: el Estado ideal será uno en el que quienes producen los bienes de consumo, campesinos y artesanos, y los que guardan la ciudad, los soldados, se subordinen 
a los que pueden, gracias a la dialéctica, conocer la verdadera realidad de las ideas; los filósofos son aquellos que han purificado su alma, quienes contemplan la más grande y más perfecta realidad, que está más allá de la esencia: la idea del Bien. E1 Estado ideal, el Estado justo, es aquél en que un filósofo gobierna o un rey filosofa.

Hacia el 367, viaja a Sicilia por segunda vez convencido por Dión, quien le asegura a Platón que Dionisio II, el Joven, está verdaderamente interesado en la filosofía y que es la ocasión que esperaban para hacer realidad el gobierno de un filósofo. El resultado es peor que el anterior. A Dión lo exilian; a Platón lo retienen contra su voluntad y no se libra hasta que se suscita una guerra local. Poco después, Dionisio mismo llama nuevamente a Platón a Sicilia, como si estuviera decidido a establecer su ideal político. Platón organiza una especie de comisión de la Academia, viaja con Espeusipo y Jenócrates, y lo hace más por amistad hacia Dión que por haber creído en Dionisio, el cual está lejos de querer someterse a la instrucción platónica y se muestra reacio a cambiar su modo disoluto de vivir. Platón fracasa en su deseo de rehabilitar a Dión ante Dionisio, y él mismo, sintiéndose en peligro, escribe a Arquitas, cuya intercesión le permite regresar a Atenas. El desenlace final es más triste: Dión organiza un golpe de Estado; después de su éxito, es asesinado en 354 por Calipo, un miembro de su propio partido.

A pesar de sus fracasos en Sicilia o gracias a ellos, Platón hace una revisión de su pensamiento político y hace una crítica de su doctrina de las ideas. Escribe Sofista (sobre el ser); Político (sobre el reino); Filebo (sobre el placer); Timeo (sobre la naturaleza); Critias (sobre la guerra entre la A tenas de los orígenes y la mítica Atlántida). La muerte encontrará a Platón, en el 347, mientras escribía Las leyes (sobre la legislación). Su sobrino Espeusipo quedará al frente de la Academia.

Desde su aparición, el pensamiento platónico se renueva cíclicamente. La más célebre de esas renovaciones fue el Renacimiento, pero no ha sido la única ni la primera, ni será la última; ya antes Plotino y los neoplatónicos habían usado a Platón para sus reflexiones, y en el siglo pasado la hermenéutica del filósofo alemán Hans Georg Gadamer se concibe a sí misma como una renovación platónica. Parecería exagerado, pero ya se ha hecho, considerar la filosofía del mundo occidental como pies de página y notas al margen de los Diálogos. Otro modo de hacer ver lo importante de su influencia es señalar al cristianismo como platonismo para las masas. Tenemos en Platón el más alto pensamiento expresado 
en la forma más bella. Cicerón decía aun las buenas traducciones parecen que si Júpiter hablara griego, sin traicionarlo, pero aun traducido, por duda lo haría como Platón. Vale la el bien nuestro y el de nuestro pensapena aprender griego para leerlo; miento, debemos leer a Platón. 
CITAM Derechos Reservados.

La reproducción total o parcial de este artículo se podrá hacer si el ITAM otorga la autorización previamente por escrito. 